\title{
Age-related patterns of volatile cephalic constituents in queens of the neotropical stingless bee Scaptotrigona postica Latr (Hymenoptera, Apidae)
}

\author{
E Engels 1, W Engels 1, G Lübke 2, W Schröder 2, W Francke 2
}

\author{
'Zoologisches Institut der Universität, Auf der Morgenstelle 28, D -72076 Tübingen; \\ 2 Institut für Organische Chemie und Biochemie der Universität, \\ Martin-Luther-King-Platz 6, D-20146 Hamburg, Germany
}

(Received 18 February 1993; accepted 30 April 1993)

\begin{abstract}
Summary - In heads of queens of the neotropical stingless bee Scaptotrigona postica identification and quantification of 68 volatile compounds was carried out by individual GC/MS analysis. Hydrocarbons, alcohols, esters, carboxylic acids, methylketones and lactones were found in distinct ontogenetic patterns. In all young queens secondary alcohols constitute $60-80 \%$ of the cephalic secretions. In receptive virgins $10-12 \mathrm{~d}$ after emergence the odour pattern contains $\approx 7 \%$ methylketones. Only in recently mated queens at the age of 12-14 d did the amount of unsaturated butyrates reach $\approx 20 \%$. In old egg-laying queens carboxylic acids $>80 \%$ ) are the main components, while Z-9-tricosene forms the major component in the neutral fraction. The presumable functions of the queen pheromone in stingless bees have been discussed in relation to reproductive biology and colony cycle.
\end{abstract}

stingless bee / reproduction / queen cephalic volatile / age-related variation / pheromone / Scaptotrigona postica

\section{INTRODUCTION}

In the highly eusocial honey bees and stingless bees, the study of mating biology has determined conformity in many respects but also distinct differences as regards certain details (Engels, 1988; Engels and Imperatriz-Fonseca, 1990). Whereas in honey bees queen pheromones are similar in composition independent of age (Free, 1987; De Hazan et al, 1989), in stingless bees 2 largely different patterns of volatile compounds exist in young and old queens (Engels et al, 1987). Evidently the odour of young queens induces lek formation by males close to nest entrances where they may wait a long time for a virgin queen (Kerr et al, 1962; Engels and 
Engels, 1984). A young queen usually undertakes several very short orientation loops before she leaves for a nuptial flight which lasts only $10 \mathrm{~min}$ or less. Single mating is highly probable since the queen returns with a mating sign which she herself removes and which takes up much time (Engels and Engels, 1988), and according to sperm counts in drone vesicles compared with the spermatheca (Kerr et al, 1962). Based on this particular premating behavior, a mating box laboratory bioassay was developed which showed Scaptotrigona postica gynes to be most attractive to drones at an age of 10-14 and particularly at $12 \mathrm{~d}$ (Engels and Engels, 1988), corresponding well to the real mating age. Eighty-five volatile compounds could be identified in the head of queen bees (Engels et al, 1990). According to the differences found in young and old queens, "copies" of the corresponding bouquets were prepared using synthetic compounds. In field bioassays, dummies impregnated with these "artificial head" blends were exposed to drone aggregations. The drones' reaction clearly indicated that they could recognize the scent of a young queen (Engels et al, 1990). This confirmed our assumption that in stingless bees, as in honey bees, cephalic volatiles are important components of the female sex pheromone. Whether ontogenetic patterns in head volatiles might distinctively label a receptive virgin by a bouquet specific for the mating age was investigated in the present study. In addition, a brief report on the development of incipient $S$ postica colonies containing young queens in the premating, mating and postmating phase respectively has been presented.

\section{MATERIALS AND METHODS}

Colonies of $S$ postica were kept in the Department of Genetics meliponary, USP Campus at Ribeirão Preto, Brazil. March through April, roy- al cells containing queen pupae were collected from strong colonies and placed in mini-nuclei. Emergence of gynes was checked daily. Young virgins were introduced into small free-flying colonies. These mating nuclei were inspected every 2 nd $\mathrm{d}$. Before the queens were dissected, their attractivity to drones was tested in the mating box bioassay (Engels and Engels, 1988).

For individual GC/MS analysis samples were taken from queens of known age and life history. The head of a queen was removed and immediately put into a small vial containing $\approx 200 \mu \mathrm{l}$ pentane (Merck Uvasol). After concentration GC/MS analyses of the extracts were carried out via a HP 5890 coupled to a VG 70/ 250 SE (Ayasse et al, 1990, 1993; Engels et al, 1990).

\section{RESULTS}

\section{Incipient nest development}

The mating nuclei were equipped with cerumen and food stores, as found in an incipient filial nest. As there was no worker traffic for transportation of material from a maternal colony, the nuclei had to be supplied with fermented pollen and syrup every 2 nd $d$. The workers usually built some pots and stored honey. The entrance of a newly established colony containing a young gyne was always closed for $6-8 \mathrm{~d}$ by a bulb. The workers did not forage during this period. Only a few d prior to the nuptial flight of the virgin was the entrance slightly reopened.

After mating of the young queen, several changes in worker behavior could be observed. The nurse bees consumed increasing amounts of pollen and constructed a small brood nest covered with an involucrum. Initially only 1 or 2 cells were built and provisioned. Older bees began to forage pollen. Usually 3-4 d after the nuptial flight the queen was seen for the first time on the small brood nest, and subsequently 
started ovipositioning. Although at this stage a young queen is already to some extent physogastric she at first lays only 36 eggs/d, but this rate increases rapidly. Normally 4 or $5 \mathrm{~d}$ after the start of egg laying, $\approx 50$ operculated brood cells are found. At $25 d$ of age the full physogastric status of an intensely laying queen is attained, and the brood nest consists of 1 000-2 000 cells. This stimulates the workers to construct an entrance funnel and to guard the nest. Forager traffic is then so heavy that reinforcement of such colonies once a wk becomes necessary, until the first young workers emerge after $\approx 50 \mathrm{~d}$.

\section{Age-related patterns of cephalic volatiles and queen attractivity}

Young and old queens differ considerably in the constitution of their cephalic volatile bouquets (fig 1). The percentage of 68 volatiles was determined in the individual pentane extracts of heads of 13 queens via quantitative GC. All identified compounds contributing to at least $0.01 \%$ of the spectrum were considered. These were 17 alcohols, 5 ketones, 29 hydrocarbons, 8 esters and 9 carboxylic acids (table I). According to the proportions of the compounds, the individual odour patterns could

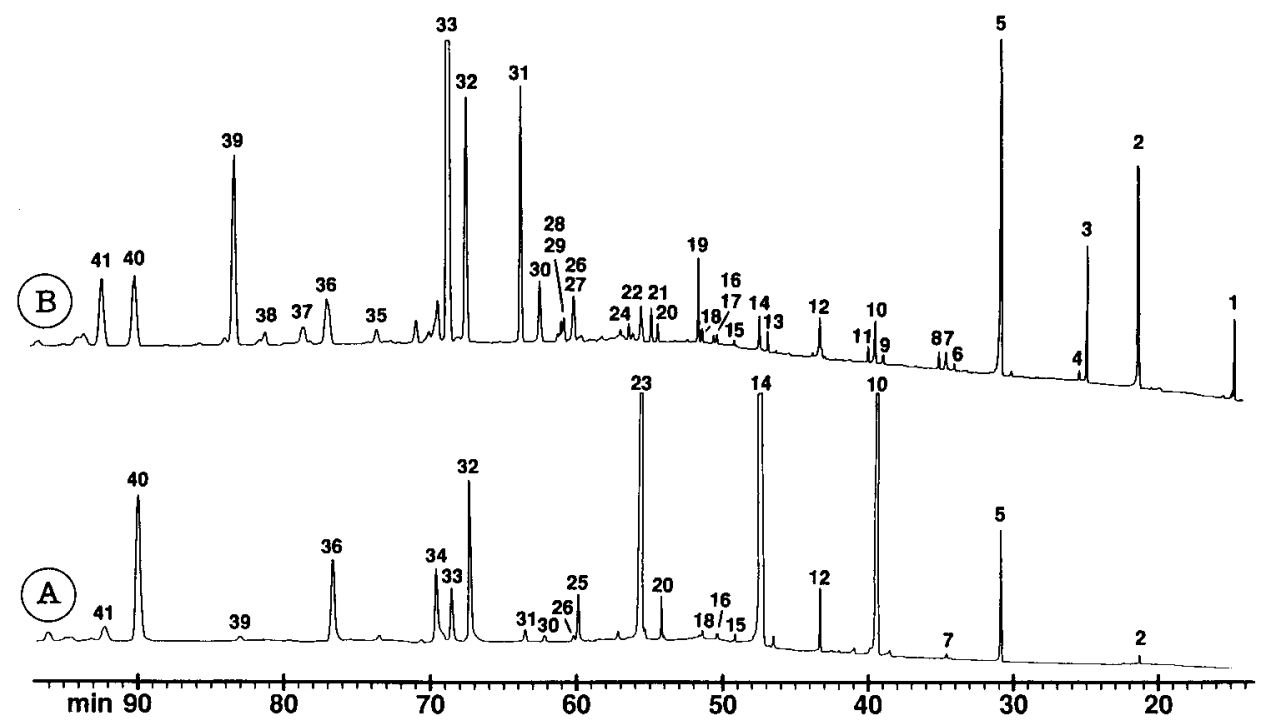

Fig 1. Gas chromatograms of cephalic pentane extracts of (A) young and (B) old Scaptotrigona postica queens. These are examples of GC analyses of individual samples which, according to the separation conditions, result in peak patterns not always showing all the minor components. The peak numbers correspond to the following compounds: 1. Heptan-2-one; 2. Heptan-2-ol; 3. Nonan-2-one; 4.Tetradecane; 5. Nonan-2-ol; 6. 2-Heptyl hexanoate; 7. Undecan-2-one; 8. Hexyl octanoate; 9. Heptadecane; 10. Undecan-2-ol; 11. N-Ethylaniline *; 12. Tridecan-2-one; 13. Nonadecane; 14. Tridecan-2-ol; 15. Dodecanol; 16. 2-Tridecyl butyrate; 17. Eicosane; 18. Pentadecan-2-one; 19. Dodecyl butyrate; 20 . Tetradecyl acetate; 21 . Heneicosane; 22 . Z-9-Heneicosene; 23. Pentadecan-2-ol; $24 . \gamma-$ Decalactone; 25. $\delta$-Decalactone; 26. Z-5-Tetradecenol; 27. Docosane; 28. Decyl octanoate; 29. Docosene; 30. Tetradecyl butyrate; 31. Z-5-Tetradecenyl butyrate; 32. Tricosane; 33. Z-9-Tricosene; 34. Heptadecan-2-ol; 35. Tricosadiene; 36. Tetracosane; 37.Dodecyl octanoate; 38. Nonadecan-2-one; 39. Z-7-Hexadecenyl butyrate; 40. Pentacosane; 41 . Z-9-Pentacosene; " : contamination. 


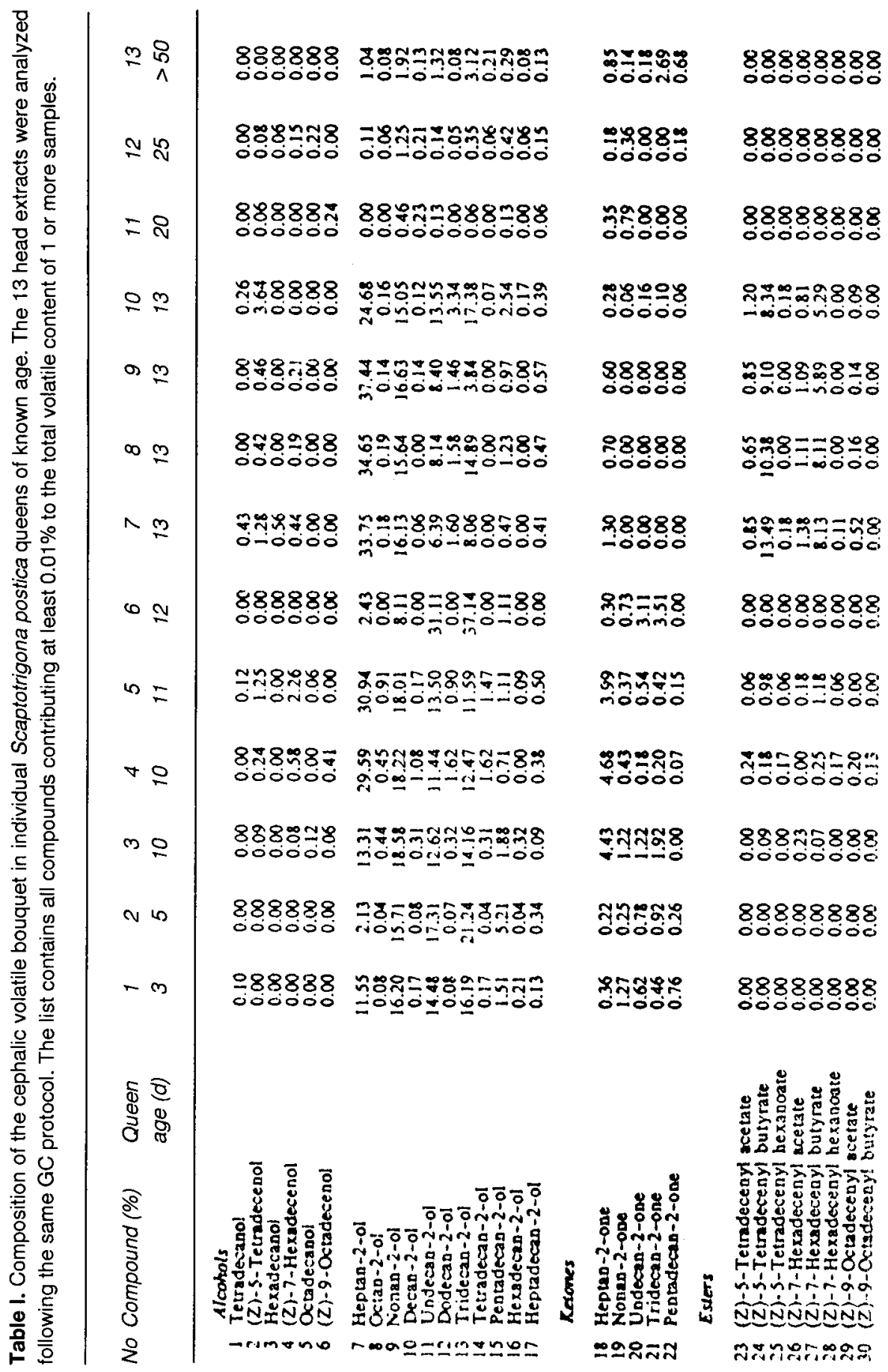




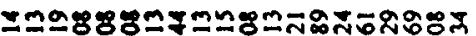

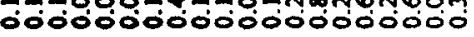

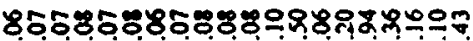
0000000000000

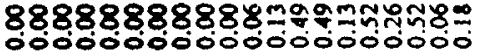

888888888888888 \%8

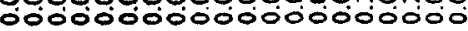

$8888888888888=878888$ 00000000000000000000

$8888888888888 \simeq 8 \simeq 8888$ 000000000000000000000

88888888888888898888 00000000000000000000

8888888888888 Rิ8ก8889 00000000000000000000

$888888888 \mathrm{~m} 8888=$ ำเ 00000000000000000000

$888888888878888=8888$ 00000000000000000000

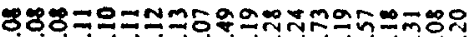
000000000000000000000

$8888888=8=508 \div 8$ ำำำำ 00000000000000000000

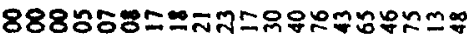
0000000000000000000
88 8ำำำำ웅 00-000000

8भरन

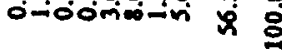

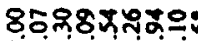

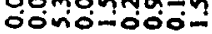

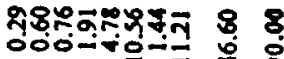
(1)

$88 \div 888=8=$

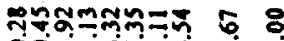

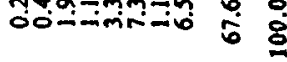

8888888용 88888888
0000000

$888888 m 8$ m 000000ํํㅇ

888888888 8 00000000 :

88888888 00000000

88888888

88 00000000 \%

$88888878 \%$ 000000000

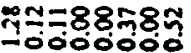

\$ั

88888888 m

000000000

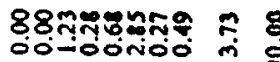

888888588 000000000

m88교요 00000000

iे 8

888888888

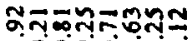
- 8

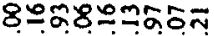
00000000

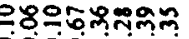
oodo-no-

38

$88 \% 888 \overline{0} 5$

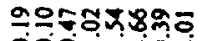
oó-mion

สิ

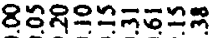

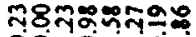
2
-8

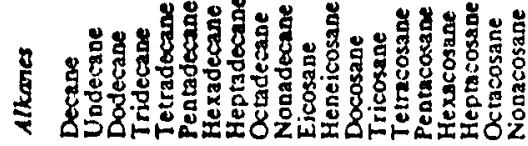

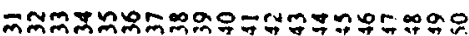
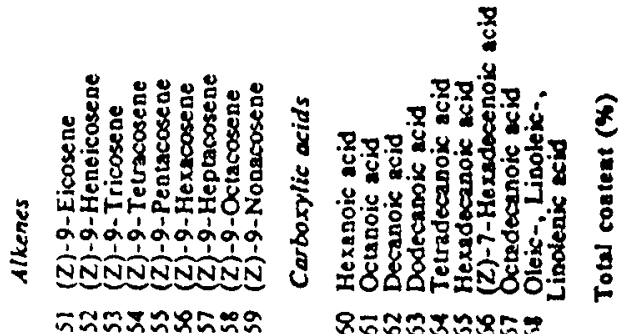

\section{8 8} 8 8

\section{8} 8 용

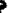

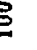

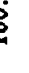

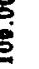


easily be grouped into 4 classes corresponding to age groups. The queens belonging to these groups were sampled $0-5,10-12,12-14$ and 20-100 d after emergence respectively, representing the physiological status of premating gynes, receptive virgins, mated young queens and egg laying, physogastric old queens (fig 2). This status was confirmed by the results of the mating box test. The premating gynes were not attractive for the drones. One of these solicited food from the males in the mating box. Only the receptive virgins received immediate copulation attempts from the drones. One was made when she had just left the nest for the mating flight. The already mated young queens were much less attractive, and the same was the case for the old physogas- tric queens. The drones in the mating box, however, copulated with one of the egglaying queens who had just been taken from a large colony.

\section{Compound patterns correlated with the queen's physiological status}

In all young queens collected $<15 \mathrm{~d}$ after emergence, the secondary alcohols represented predominant volatiles in the cephalic extracts (fig 2). In 10-14-d-old queens, the 2-alkanols constituted $75 \%$ of the bouquet. In contrast, in the old egg-laying queens the amount of alkanols was reduced to $<5 \%$. Instead carboxylic acids were found to be the main compounds, av-
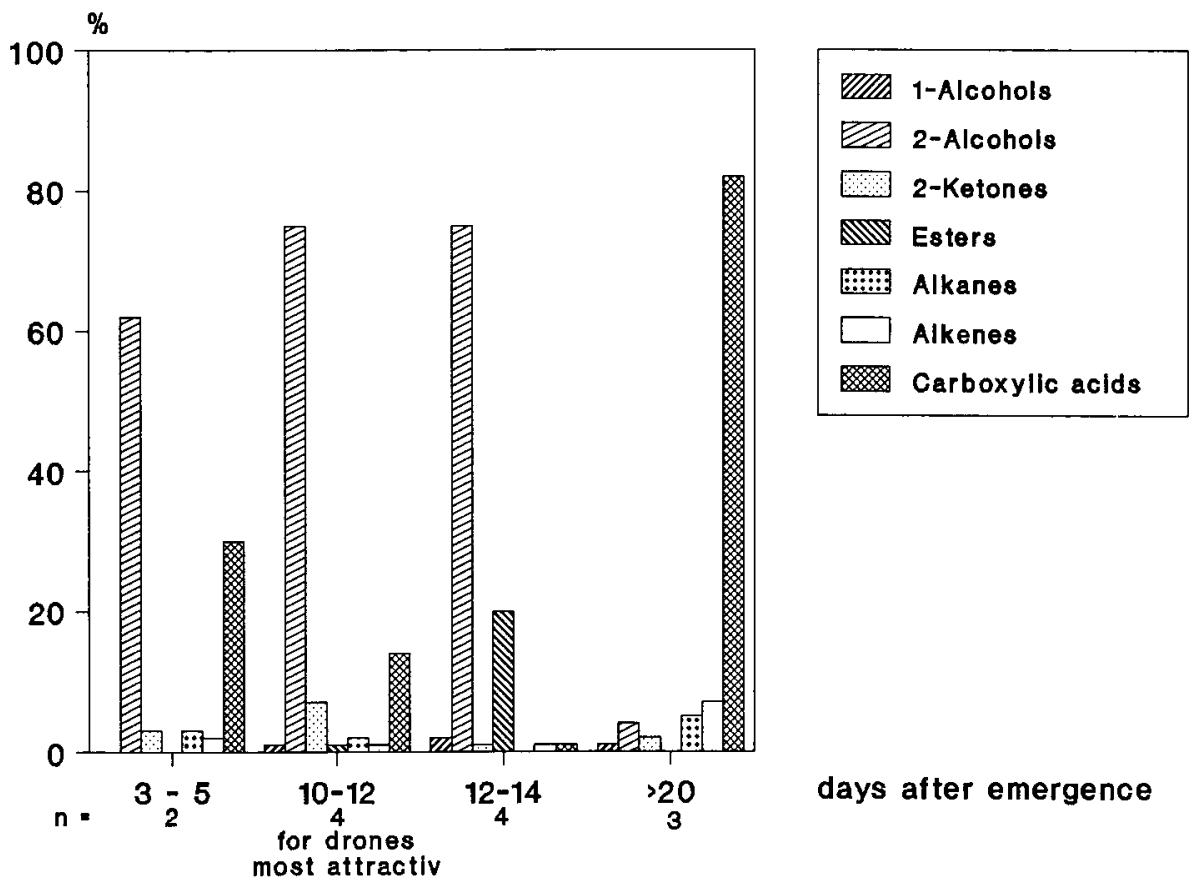

Fig 2. Proportions of compound groups found in the cephalic volatile bouquet of Scaptotrigona postica queens of different physiological status. 4 distinct ontogenetic patterns can be distinguished. 
eraging $\approx 80 \%$. In newly emerged gynes, the carboxylic acid content was $\approx 30 \%$. In the cephalic extracts of receptive and highly attractive virgins, a mean content of $7 \%$ methyl ketones was calculated. In all other groups, the percentage of ketones was much less. Butyrates of straight-chain unsaturated primary alcohols were found to contribute $\approx 20 \%$ to the bouquet only in young but already mated queens. The $7 \%$ mean hydrocarbon content present in the head extracts of old physogastric queens was high compared to that in younger individuals.

\section{DISCUSSION}

The worker's closure of the entrance to an incipient nest containing a gyne not yet ready for mating may prevent the premature formation of a drone aggregation. This "closed-door state" of a filial nest might also prevent other gynes from the maternal colony or neighbouring nests from entering and displacing the resident virgin. The bulb constructed by incipient colonies to close the entrance resembled the sealing observed during long-lasting cold rainy periods.

The data on cephalic volatile composition in individual $S$ postica queens clearly indicate not only pronounced differences in the odour bouquet of young and old queens (Engels et al, 1987, 1990), but also a distinct age-related pattern that gradually changes, in particular during the first 2 wk after emergence. This raises questions concerning the reasons for such ontogenetic patterns in adult queen cephalic volatiles with respect to stingless bee reproductive biology.

In contrast to honey bees (Velthuis, 1985), stingless bee queens are not always attractive to workers, which pursue and often kill a young gyne (Engels and Imperatriz-Fonseca, 1990). In S postica only during the brief mating period at $\approx 12$ $\mathrm{d}$ after emergence is a virgin highly attractive to the males (Engels and Engels, 1988). However, already a few d prior to the short nuptial flight drones form a lek aggregation close to the colony (Kerr et al, 1962; Engels and Engels, 1984). In a receptive virgin, evidently the highly volatile secondary alcohols comprising $60-80 \%$ of the cephalic bouquet in young queens are involved in mate attraction, as in field tests using a dummy impregnated with the 4 major 2-alkanols, drones in an aggregation were found to be attracted (Engels et al, 1990). After a successful mating flight, the young queen becomes much less attractive to the drones (Engels and Engels, 1988). She still has to be accepted by the colony (Engels and Imperatriz-Fonseca, 1990). Only the egg-laying and physogastric queen attains a stable dominant royal status (Engels, 1986).

In stingless bees, the queen apparently contributes important information to nest odour. Only in the event that a virgin is present in a colony is the formation of a drone aggregation released. Since after a successful mating flight this lek assembly in the vicinity of a filial nest soon disintegrates (Engels and Engels, 1984), the nest odour must change, signalling to the males that they can no longer expect to find a virgin.

Another question is that of a possible negative label regarding a recently mated queen. Is there a post-copulation message indicating to the drones that this young queen is no longer receptive? In the primitively eusocial halictine bee Lasioglossum malachurum, the volatile composition of the Dufour's gland secretion changes significantly within $1 \mathrm{~d}$ after mating (Ayasse et al, 1993). It is interesting to note that the butyrates found in high proportions only in such $S$ postica queens show some structural relationship to certain acetates which are typical sex pheromones in Lepidopte- 
ran females (Arn et al, 1992). Under natural conditions the mated queen will not undertake another nuptial flight, and therefore normally will not meet any more mature drones which in stingless bees colonies always leave the maternal colony and act as vagabonds (Engels and Engels, 1984; Engels, 1987). In the mating box bioassay drones confronted with a recently mated young queen showed little interest (Engels and Engels, 1984; confirmed by the biotest results reported here).

The post-mating transition of the young queen to the status of an accepted egglaying head of the colony (Engels and Imperatriz-Fonseca, 1990) has a prominant influence on the workers' behaviour. Construction and provisioning of brood cells as well as laying of alimentary eggs is stimulated in young nurse bees, whereas colony defense and foraging is intensified in old field bees (Engels et al, 1979). In the honey bee, a similar stimulation, and in addition retinue formation (which is not observed in a comparable manner in stingless bees), is released by a blend of major components present in the queen's mandibular gland secretions (Slessor et al, $1988,1990)$. Whether in physogastric $S$ postica queens cephalic volatiles represent this dominance signal function, perhaps in combination with the secretions from the large abdominal tergal glands in stingless bee queens(Cruz-Landim et al, 1980), still has to be investigated. In the head extracts of old and egg-laying queens, $Z-9$-tricosene constitutes the main hydrocarbon; this compound is widespread among insects and is also known as a sex pheromone component in female house flies (Adams, 1986).

\section{ACKNOWLEDGMENTS}

This study was carried out in cooperation with the Departments of Genetics and Biology, Uni- versity of São Paulo, Campus Ribeirão Preto. We appreciate the facilities kindly provided by our colleagues, ZLP Simões and LS Gonçalves. The work was supported by DFG grants (Schwerpunkt Chemische Ökologie En 89/11 and Fr 507/8).

Résumé - Analyse en fonction de l'âge des constituants volatils des glandes céphaliques chez les reines de Scaptotrigona postica, mélipone néotropicale. On a déterminé par chromatographie en phase gazeuse (fig 1) la concentration de 68 composés volatils (fig 2) provenant d'extraits au pentane de têtes de reines de Scaptotrigona postica. Une série de 13 reines d'âge connu, élevées dans un rucher expérimental à l'université de São Paulo à Ribeirão Preto, a été analysée. Les résultats montrent des différences entre les pourcentages des divers composés. Ces différences peuvent être considérées comme un profil ontogénétique qui permet de séparer nettement les jeunes reines avant, au moment de l'accouplement et après, ainsi que les vieilles reines pondeuses (fig 2). Chez les jeunes reines les alcools secondaires dominent, formant 60 à $80 \%$ du bouquet. Chez les vieilles reines physogastriques ils ne représentent plus que $5 \%$, alors que les acides carboxyliques représentent plus de $80 \%$. Le Z-9tricosène est le composé principal de la fraction neutre de cette classe d'âge. Les reines vierges réceptives se caractérisent par un bouquet odorant typique de l'âge de $10-12 \mathrm{j}$ et qui se compose de 5 à $10 \%$ de méthylcétone. Seules les jeunes reines qui viennent de s'accoupler présentent un pourcentage relativement élevé d'esters ( $20 \%$ de butyrates insaturés). Le développement du nid chez cette espèce de mélipone est brièvement décrit. On discute des fonctions possibles de la phéromone royale en rapport avec la biologie de la reproduction et le cycle de la colonie, qui présentent des différences par rapport à l'abeille domestique. 
Meliponinae / Scaptotrigona postica / reproduction / glande céphalique / phéromone / composé volatil / effet âge

\section{Zusammenfassung - Alterskorrelierte Muster in der Zusammensetzung flüch- tiger Inhaltsstoffe von Kopfdrüsen bei} Königinnen der neotropischen stachellosen Biene Scaptotrigona postica. In den Köpfen einzelner Königinnen der neotropischen stachellosen Biene Scaptotrigona postica wurde mittels Gaschromatographie (Abb 1) die Konzentration von 68 flüchtigen Inhaltsstoffen in Pentanextrakten von Einzelköpfen bestimmt (Abb 2). Die Analysenergebnisse einer Serie von 13 altersbekannten Königinnen, die in Brasilien auf einem Versuchsbienenstand der Universität von São Paulo in Ribeirão Preto gehalten wurden, ergaben charakteristische Unterschiede in den Anteilen der Einzelkomponenten. Sie lassen sich als ontogenetisches Muster interpretieren, aufgrund dessen Jungköniginnen vor, während und nach dem Paarungsalter sowie eierlegende Altköniginnen sich klar unterscheiden (Abb 2). Bei Jungköniginnen dominieren sekundäre Alkohole mit Anteilen von $60-80 \%$ am Bouquet. Bei physogastrischen Altköniginnen machen diese nur noch unter $5 \%$ aus, Carbonsäuren dagegen über $80 \%$. Z-9-Tricosen ist die Hauptkomponente in der Neutralfraktion dieser Altersstufe. Paarungsbereite Jungköniginnen zeichnen sich durch ein für das Alter von 10-12 Tagen typisches Duftmuster aus, das $5-10 \%$ Methylketone enthält. Bereits begattete Jungköniginnen hingegen weisen einen relativ hohen Anteil von Estern auf, nämlich etwa $20 \%$.

In einem kurzen Abriß wird die Nestentwicklung bei dieser Art stachelloser Bienen beschrieben. Mögliche Funktionen des Königin-Pheromons werden in Zusammenhang mit der Fortpflanzung und dem Nestzyklus diskutiert, wobei Unterschiede zu dem von Honigbienen Bekannten aufgezeigt werden.

Stachellose Bienen / Fortpflanzung / Königin-Kopfduftstoffe / Ontogenetische Pheromon-Muster

\section{REFERENCES}

Adams T S (1986) Effect of different female produced pheromone components on male courtship behavior in the house fly, Musca domestica. Adv Invertebr Reprod 4, 297-304

Arn H, Tóth N, Priesner E (1992) List of sex pheromones of Lepidoptera and related attractants. In: Int Organ Biol Control (IUBC). INRA, Montfavet, 2nd, $179 \mathrm{pp}$

Ayasse $M$, Engels $W$, Hefetz $A$, Lübke $G$, Francke W (1990) Ontogenetic patterns in amounts and proportions of Dufour's gland volatile secretions in virgin and nesting queens of Lasioglossum malachurum (Hymenoptera: Halictidae). $Z$ Naturforsch $45 c$, 709714

Ayasse M, Engels W, Hefetz A, Tengö J, Lübke G, Francke W (1993) Ontogenetic patterns of volatiles identified in Dufour's gland extracts from queens and workers of the primitively eusocial halictine bee, Lasioglossum malachurum (Hymenoptera: Halictidae). Insectes Soc 40, 41-58

Cruz-Landim C da, Höfling M C A, ImperatrizFonseca V L (1980) Tergal and mandibular glands in queens of Paratrigona subnuda (Moure) (Hymenoptera: Apidae). Morphology and associated behaviour. Naturalia 5, 121133

Engels E, Engels W (1984) DrohnenAnsammlungen bei Nestern der stachellosen Biene Scaptotrigona postica. Apidologie 15, 315-328

Engels E, Engels W (1988) Age-dependent queen attractiveness for drones and mating in the stingless bee, Scaptotrigona postica. $J$ Apic Res 27, 3-8

Engels E, Engels W, Francke, W (1987) Do stingless bees have two complexes of queen substances? In: Chemistry and Biology of Social Insects (Eder J, Rembold H, eds) Verlag Peperny, Munich, 710-711 
Engels W (1986) The concept of chemical communication in arthropods as realized in social bee reproduction. Adv Invertebr Reprod 4, 285-296

Engels W (1987) Pheromones and reproduction in Brazilian stingless bees. Mem Inst Oswaldo Cruz 82, suppl III, 35-45

Engels W (1988) Fortpilanzungsstrategien bei Bienen. Reproductive strategies in bees. Verh Dtsch Zool Ges 81, 155-167

Engels W, Imperatriz-Fonseca VL (1990) Caste development, reproductive strategies and control of fertility in honey bees and stingless bees. In: Social Insects, an Evolutionary Approach to Castes and Reproduction (Engels W, ed) Springer Verlag, Berlin, 167-230

Engels W, Engels E, Lotz G, Dröscher R, Wittmann $H$ (1979) Nestbiologie der stachellosen Biene Scaptotrigona postica. Hochschulunterrichts-Farb-Ton-Film 16 mm, IWF-Nr C 1351, Göttingen

Engels W, Engels E, Lübke G, Schröder W, Francke W (1990) Volatile cephalic secretions of drones, queens and workers in rela- tion to reproduction in the stingless bee, Scaptotrigona postica (Hymenoptera: Apidae: Trigonini). Entomol Gen 15, 91-101

Free J B (1987) Pheromones of Social Bees. Chapman and Hall, London, $218 \mathrm{pp}$

De Hazan M, Lensky J, Cassier P (1989) Effects of queen honeybee (Apis mellifera $L$ ) ageing on her attractiveness to workers. Comp Biochem Physiol 93A, 777-783

Kerr W E, Zucchi R, Nakadaira J T, Butolo J E (1962) Reproduction in the social bees (Hymenoptera: Apidae). J NY Entomol Soc 70, 265-276

Slessor K N, Kaminski L A, King G G S, Borden $J$ H, Winston M L (1988) Semiochemical basis of the retinue response to queen honey bees. Nature 332, 354-356

Slessor K N, Kaminski L A, King G G S, Winston $M L$ (1990) Semiochemicals of the honey bee queen mandibular glands. $J$ Chem Ecol 16, 851-860

Velthuis H H W (1985) The honey bee queen and the social organization of her colony. Fortschr Zoo/31, 343-357 